\title{
Identification of public perception to the teacher's social competences and status
}

\author{
Muhammad Takwin Machmud \\ Department of Research Educational \\ and Evaluation \\ Naresuan University \\ Phitsanulok, Thailand \\ takwin m@yahoo.com
}

\author{
Omthajit Pansri \\ Department of Research Educational \\ and Evaluation \\ Naresuan University \\ Phitsanulok, Thailand
}

\author{
Mushawwir Taiyeb \\ Faculty of Biology \\ Universitas Negeri Makassar \\ Makassar, Indonesia
}

\author{
Andi Bulqis \\ Faculty of Biology \\ Universitas Negeri Makassar \\ Makassar, Indonesia
}

\author{
Moh. Sahrul \\ Faculty of Biology \\ Universitas Negeri Makassar \\ Makassar, Indonesia
}

\begin{abstract}
Public believes that the teacher is someone who is highly respected because of their ability to educate and reforming the character of students to be a better individual. This study tries to identify public perception about teachers quality based on their social competences. The subject in this study is a public who live in Indonesia and selected as sample using purposive sampling technique. This study used total 40 people as a sample who has a different background (occupation) which will divide into two group based on their economic status. This study is using the questionnaire as the instrument to collect the data from the respondent. The questionnaire consists of the item that asked about public perception about teacher social competences. The result of this study shows that there are some different response from the respondent, this thing happen because every individual has a different experience when they do communication with the teachers.
\end{abstract} status

Keywords—teachers; teacher social competences; teacher social

\section{INTRODUCTION}

Teachers become the critical actor in the educational process. The success of the of national education can be seen by the quality and performance of their teachers. According to Darling-Hammond, the quality of education that assess based on students learning achievement is determined by teachers. Moreover, the teacher role in developing country has about $34 \%$ impact factor to the students learning achievement and for the industrial country is about $36 \%$ [1].

People think that teachers have an easy job because they just teach students and didn't spend more energy like the other profession. However, the most important thing that we have to know that teachers have a high responsibility to build the good quality individual. As Indonesian Government Regulation No. 14 The year 2005 Article 1 about teachers duties, states that "Teacher is a professional educator who must educate, guide, assess, and evaluate the learners in formal pre-school, elementary school, and high school."

In general, educational expert and society are complaining about the teacher quality today, which give a real impact on the declining quality of education. They believe this problem is causing several factor such pedagogic and professional competencies. An expert mentioned factor which causes lack of educational quality, such as lack of quality, lack of motivation, lack of reading interest, teachers have not creativity and innovation [2]. Moreover, the inability of the teacher to be the role model for their student, causing the public more skeptical to the social and personal competencies of teachers.

Nowadays, the social perspective of teachers was changing because the media provide news about the teacher's violence in the school. Besides that, the teachers openness responses to the public about the learning development program for students which make the public complain about the quality of teacher social competences. Social competences one of significant competencies that teacher must be based on the Indonesian regulation for the teacher define about social competences is the ability of the teacher to do an adequate communication to their environment which has a purpose to develop the quality of national education system. Based on the previous definition, by fulfilled this competency the teachers will more respectful of their job as teachers.

Although, this profession was seen as an honorable and noble profession, and most of the people believe that the teacher is someone who is highly respected for their ability to educate and reforming the character of students to be a better individual. Hargreaves et al. show that teacher place as a third most respected profession after doctors and nurses [3]. This present study aims to identify what is a public perception about teachers social competences which became a public complaint and to know teachers status in social communities. 


\section{METHOD}

\section{A. Sample}

The sample group consisted of 40 people who have a different occupation (Table 1). The respondent is chosen by using simple random sampling technique. This sampling technique is the technique which possibly to choose the set of the object in a population that has an equal probability of being chosen as a sample. Mostly this sampling technique is using to choose the sample for the quantitative study.

\section{TABLE I. DISTRIBUTION OF EMPLOYMENT}

\begin{tabular}{|l|l|l|}
\hline No & \multicolumn{1}{|c|}{ Occupation } & \multicolumn{1}{|c|}{ Total } \\
\hline 1 & Pharmacist & 7 \\
\hline 2 & Doctor & 2 \\
\hline 3 & Police & 3 \\
\hline 4 & Nurse & 3 \\
\hline 5 & Technicians & 1 \\
\hline 6 & Banker & 1 \\
\hline 7 & Private employee & 9 \\
\hline 8 & Labor & 3 \\
\hline 9 & Grocer & 3 \\
\hline 10 & Driver & 2 \\
\hline 11 & Barber & 1 \\
\hline
\end{tabular}

\section{B. Data Collecting Technique}

The method that used in this study is a quantitative method by using questionnaire [4], [5]. The questionnaire that used a Likert scale to answer each indicator or statement. The item that asked is about public perception about teacher social competences. Distribution of the questionnaire to the public through paper-based technique and online form (via google form). From 40 questionnaire form that spread into public, only 35 respondent that give their feedback.

\section{Data Analysis Technique}

Data analysis is a procedure that researcher have to conduct after collecting the data from the sample. In this study researcher used data analysis technique of quantitative research which consists of reliability (using alpha Cronbach) and descriptive analysis.

\section{Time and Place}

This study held in February 2017, which involved 40 people who stay or work around Biringkanaya District. This District is a suburb area of Makassar, which is easiest to find a various occupation in this area.

\section{RESUlT AND DISCUSSION}

The discussion for the result of this study is divided into two part, that is The first part shown the reliability of the instrument which refers to the quality of instrument that used in this study. The second part is shown the result of public perspective through the questionnaire instrument which contains several items about teacher social competences.

\section{A. Reliability}

The result of reliability analysis that research conducted by using SPSS 17.0, show that the score of reliability is .838. The acceptable values of alpha, ranging from 0.70 to 0.95 . Moreover, he also said that the maximum alpha value of 0.90 had been recommended. It means the value of alpha that researcher got from statistical analysis has been accepted ( $.838>.70)[6]$.

\section{B. Descriptive analysis}

The result of a survey that aims to identify public perception to the teacher's social competencies and status. The result shows that each item has a various feedback from the respondent. The different of respondent feedback is showing that every single person has a different experience when doing a communication with teachers.

TABLE II. DISTRIBUTION OF EMPLOYMENT

\begin{tabular}{|c|c|c|c|c|c|c|}
\hline \multirow{2}{*}{ No. } & \multirow{2}{*}{ Item } & \multicolumn{5}{|c|}{ Scale (percent) } \\
\hline & & $S A^{*}$ & $A^{*}$ & $N^{*}$ & $D^{*}$ & $S D^{*}$ \\
\hline 1 & Teachers still rated as a respected and nobility profession. & 62.9 & 34.3 & - & 2.9 & - \\
\hline 2 & Teachers performances are decreases; it seems like they are not serious to do their job. & 37.1 & 28.6 & 11.4 & - & 22.9 \\
\hline 3 & Most teachers today doing their job because salary & 40 & 34.3 & 8.6 & 14.3 & 2.9 \\
\hline 4 & Teachers are asking the students parent to keep and control their son/daughter activities. After schools & 37.1 & 51.4 & 2.9 & 8.6 & - \\
\hline 5 & $\begin{array}{l}\text { Sometimes teachers give their time to discuss learning program and students development with students } \\
\text { parents }\end{array}$ & 20 & 65.7 & - & 11.4 & 2.9 \\
\hline 6 & Sometimes teachers give counseling to the society about current educational program & 20 & 30 & 11.4 & 28.6 & - \\
\hline 7 & Today's teachers uphold the values of honesty & 40 & 28.6 & 11.4 & 17.1 & 2.9 \\
\hline 8 & Today's teachers have more assertively & 34.3 & 31.4 & 5.7 & 28.6 & - \\
\hline 9 & Today's teachers have not humanity sense when they give punishment to student & 25.7 & 17.1 & 14.3 & 31.4 & 11.4 \\
\hline 10 & Teachers used a polite word and kept the tone when discussing with the student parents. & 37.1 & 60 & - & 2.9 & - \\
\hline 11 & $\begin{array}{l}\text { Mostly teachers give special treatment and do a good communication with the student's parents who have } \\
\text { good social status. }\end{array}$ & 42.9 & 28.6 & 5.7 & 20 & 2.9 \\
\hline 12 & $\begin{array}{l}\text { Teachers give a high score in the examination to the students who have close relation with me (especially } \\
\text { family). }\end{array}$ & 37.1 & 37.1 & 5.7 & 14.3 & 5.7 \\
\hline
\end{tabular}

a. * $\mathrm{SA}=$ Strongly Agree; $\mathrm{A}=$ Agree; $\mathrm{N}=$ Neither; $\mathrm{D}=$ Disagree; $\mathrm{SD}=$ Strongly Disagree) 
According to the data that shown in table 2, the item number 1 which asking about "teachers still rated as a respected and nobility profession," about $62.9 \%$ respondent said strongly agree, and about $34.3 \%$ respondent agree with that statement. Only $2.9 \%$ respondent said disagree which means most people still believe that the status social of teachers as an honorable and respected profession still high.

Item number 2 and three are focusing on public perception about teacher performances today. Item number 2 shown about $37.1 \%$ respondent are strongly agreed, and $28.4 \%$ respondent agrees, which means public believes that today teacher has not good performance when they do their job. On the other hand, mostly respondent about $40 \%$ (strongly agree) and 28.6 (agree) that salary is not the main problem of teachers to do their job. For the item number, 4 to 6 are explained about the effectiveness of teachers communicate about educational program and development of the student to the parents, public, the other stakeholder. Mostly respondent showed their agreement that teachers always conform to the public about the educational program and development of the student.

Item number 7 to 10 are an attempt to identify the personality of the teacher. For the personal characteristic such as honesty, assertively, and polite, most of the respondent showed that teacher has an excellent personal characteristic. Except for the item which asked about humanity sense, which the percentage for each scale almost equal. Although the most answer from respondent shown that the teacher still has humanity sense.

The last two item try to identify about discrimination that teachers do against students, parents of students and the school stakeholders because of different background, and socioeconomic status. Most of the respondent believe if teachers still discriminate someone based on their background and social status.

\section{CONCLUSION}

As the Conclusion, the result of this study about public perception to the social competencies and status of teacher shown that the public still believes that the teacher's profession is a respected and nobility profession. Even there is some lack of performances of teachers today. The other things that shown from this initial study that the social competencies of today teachers, most of the respondent give their good feedback that teachers still have an excellent social competences. However, the teacher still does the discrimination in the educational process. For the personal aspect, public believes that teacher still has a good personality as a role model for the public.

\section{REFERENCES}

[1] L. Darling-Hammond, "Teacher quality and student achievement," Educ. Policy Anal. Arch., vol. 8, p. 1, 2000.

[2] M. Antikainen, M. Mäkipää, and M. Ahonen, "Motivating and supporting collaboration in open innovation," Eur. J. Innov. Manag., vol. 13, no. 1, pp. 100-119, 2010.

[3] L. Hargreaves, M. Cunningham, T. Everton, A. Hansen, B. Hopper, D. McIntyre, M. Maddock, J. Mukherjee, T. Pell, and M. Rouse, "The status of teachers and the teaching profession: Views from inside and outside the profession," Interim Find. From Teach. Status Proj., 2006.

[4] S. Kumar and P. Phrommathed, Research methodology. Springer, 2005.

[5] C. R. Kumar, Research Methodology. APH Publishing Corporation, 2008.

[6] M. Tavakol and R. Dennick, "Making sense of Cronbach's alpha," Int. J. Med. Educ., vol. 2, p. 53, 2011. 